\title{
Trypanosoma cruzi isolated from a triatomine found in one of the biggest metropolitan areas of Latin America
}

\author{
Aline Rimoldi Ribeiro[1], Rosane Correa de Oliveira ${ }^{[2]}$, Walter Ceretti Junior ${ }^{[3]}$, \\ Luciana Lima ${ }^{[4]}$, Larissa Aguiar de Almeida ${ }^{[5]}$, Juliana Damieli Nascimento ${ }^{[1]}$ \\ Marta Maria Geraldes Teixeira ${ }^{[4]}$ and João Aristeu da Rosa ${ }^{[5]}$
}

[1]. Departamento de Biologia, Universidade Estadual de Campinas, Campinas, São Paulo, Brasil. [2]. Secretaria Municipal de Saúde de São Paulo, São Paulo, Brasil [3]. Faculdade de Saúde Pública, Universidade de São Paulo, São Paulo, Brasil. [4]. Departamento de Parasitologia, Universidade de São Paulo, São Paulo, Brasil. [5]. Departamento de Ciências Biológicas, Universidade Estadual Paulista Júlio de Mesquita Filho, Araraquara, São Paulo, Brasil.

\begin{abstract}
Introduction: To characterize Trypanosoma cruzi (TcI) isolated from a Panstrongylus megistus specimen found in one of the biggest metropolitan areas of Latin America, the relationship between the TcI group of $T$. cruzi and the transmission cycle in the urban environment was studied. Methods: The T. cruzi strain, Pm, was isolated in a culture medium from the evolutionary forms present in the hindgut of a live male specimen of P. megistus found in the Jabaquara subway in São Paulo City. The sample from the triatomine showed trypomastigote forms of Trypanosomatidae, which were inoculated in the peritoneum of Balb/c mice. The sample was then inoculated in Liver Infusion Tryptose medium and J774 cells for the molecular identification and characterization of the parasite. The Pm strain of T. cruzi was identified by isolation in axenic culture medium, and based on the morphology, cell infection, growth kinetics, and molecular characterization. Results: After isolation, the protozoan was identified as $T$. cruzi. No parasites were detected in the peripheral blood of the animal, which can be a characteristic inherent to the strain of $T$. cruzi that was isolated. Cell invasion assays were performed in triplicate in the J774 cell line to confirm the invasive ability of the Pm strain and revealed amastigote forms of the parasite within macrophages. Conclusions: Our biological and molecular characterizations helped understand parasite-host interactions and their evolutionary history in context of the associations between vectors, ecotopes, hosts, and groups of the parasite.
\end{abstract}

Keywords: Trypanosoma cruzi. Panstrongylus megistus. Molecular characterization. Chagas disease.

\section{INTRODUCTION}

Triatomine species are vectors of Trypanosoma cruzi, the etiological agent of Chagas disease, and so far, 148 Triatomine species have been described ${ }^{(1)(2)}$. Since the description of new human trypanosomiasis in 1909 by Chagas $^{(3)}$, who showed that T. cruzi infection in Panstrongylus megistus, the protozoan has been considered epidemiologically important owing to its wide distribution; the Atlantic Forest is considered its center of dispersion ${ }^{(4)}$. According to Galvão et al.$^{(5)}$, Panstrongylus megistus species have been found in the States of Alagoas, Bahia, Ceará, Espírito Santo, Goiás, Maranhão, Mato Grosso, Mato Grosso do Sul, Minas Gerais, Pará, Paraíba, Paraná, Pernambuco, Piauí, Rio de Janeiro, Rio Grande do Norte, Rio Grande do Sul, Santa Catarina, São Paulo, and Sergipe.

Corresponding author: Dra. Aline Rimoldi Ribeiro.

e-mail: line2rimoldi@gmail.com

Received 26 October 2015

Accepted 8 April 2016
Epidemiological surveillance in the State of São Paulo focuses on control actions based on the infestation levels registered in systematic searches in infested areas and residences of people who have reported the presence of triatomines ${ }^{(6)}$. Vector control in São Paulo has been successful since 1990, particularly for Triatoma infestans ${ }^{(7)}$. However, Leite et al. ${ }^{(8)}$ have identified 109 specimens of T. infestans in a peridomestic area in the City of Paulínia, which indicates the possibility of reintroduction of species such as T. infestans, Triatoma sordida, and P. megistus, which showed T. cruzi infection rates of $2.7 \%$, $0.6 \%$, and $6.4 \%$, respectively, from 1968 to $2007^{(7)}$. The presence of T. sordida and P. megistus in the State of São Paulo results from their ability to invade and colonize human habitations ${ }^{4}$. After the control of T. infestans infection, P. megistus stands out in epidemiological terms as an entomological indicator of home infestation, and studies on the density ${ }^{(5)}{ }^{(9)}$ showed that, in the State of São Paulo, about $1 \%$ of the T. sordida and $9 \%$ of the P. megistus species tested positive for T. cruzi infection. According to Silva et al. ${ }^{(10)}$, Panstrongylus megistus is an important vector for $T$. cruzi infection in the state, with high rates of natural transmission. In addition, given that $P$. megistus is native to the Atlantic Forest where Forattini ${ }^{(11)}$ and De Paula et al. ${ }^{(12)}$ examined specimens with high (8.3\%) rates of $T$. cruzi infection, surveillance on this species cannot be ignored. 
According to Barreto ${ }^{13}$, most triatomines retain their primitive wild habits. Although they are often found to be naturally infected, triatomines are rarely or never exposed to humans, and, therefore, play a prominent role in the sylvatic cycle of $T$. cruzi, but have a small epidemiological significance to humans. On the other hand, domiciled or synanthropic species of triatomines live in close contact with humans, making them responsible for the domestic cycle of $T$. cruzi infection; such triatomines are therefore considered important from an epidemiological point of view. Between these two extreme scenarios, there is a series of gradual transitions, as observed in P. megistus.

Factors such as species diversity, environmental changes, and residence invasion allow vector-mediated transmission of Chagas disease $^{(14)}$. For example, in their study in Columbia, Cordovez et al. ${ }^{(15)}$ showed that climatic changes can interfere with the route of vector-mediated transmission of the disease. The domiciliation of triatomines is essentially a dynamic phenomenon and can be explained by the relationship between some species and their natural and artificial ecotopes ${ }^{(13)}$. The domiciliation of P. megistus, which is in line with the adaptability of this species could be the reason for the high rate of T. cruzi infection ${ }^{(5)}$. Panstrongylus megistus and small mammals have been found to cohabitate since the beginning of the last century, and the first occurrence of P. megistus in natural environments was reported in the State of São Paulo ${ }^{(16)}$. The presence of $P$. megistus in natural environments represents possible sources of infestation and re-infestation and contributes to the maintenance of the life cycle of $T$. cruzi ${ }^{(17)}$. Panstrongylus megistus was found in the City of São Paulo, which has been known to have a higher rate of infection in triatomines associated with opossums and rodents ${ }^{(18)}$. Although P. megistus can adapt to human habitation and its dependencies, it can also be found in different natural ecotopes participating in the sylvatic cycle of $T$. cruzi owing to its involvement in the transport of the parasite to artificial ecotopes and in the initial infestation or reinfestation of these ecotypes ${ }^{(19)}$. Forattini et al. ${ }^{(11)}$ found P. megistus foci in hollow trees inhabited by bats, rodents, birds and, mainly, opossums. In artificial ecotopes, P. megistus feeds on humans, domestic animals (especially dogs and cats), commensal mammals (rats), synanthropic mammals (bats and possums), and birds $^{(20)(21)}$, which results in high infection rates and is also an important link in the domestic transmission cycle of T. cruzi $i^{(13)}$.

In this study, we report $T$. cruzi infection in a P. megistus specimen found in the Jabaquara subway yard in the City of São Paulo. Our finding raises the possibility that this P. megistus specimen came from the Fontes do Ipiranga State Park ( $23^{\circ} 38^{\prime} 55.40^{\prime \prime} \mathrm{S}$ to $\left.46^{\circ} 37^{\prime} 18.21^{\prime \prime} \mathrm{O}\right)$, which is $2 \mathrm{~km}$ away from the place where the triatomine was found. Our results reemphasize the need for constant surveillance on T. cruzi infection in P. megistus.

\section{METHODS}

\section{Isolation}

The Trypanosoma cruzi strain, Pm, was isolated in culture medium from the evolutionary forms present in the hindgut of a live male specimen of $P$. megistus. The triatomine was found in the Jabaquara subway, more specifically on the mezzanine hallway, Block H “2338'41.94 S to 46³8'29.46O” (Office for Logistics and Storage of Products of the Subway, Responsible Rosane Correa de Oliveira), which is an urban area in the City of São Paulo. The biological material obtained by abdominal compression was diluted in $0.9 \%$ saline and observed between the slide and the cover slip under an optical microscope ${ }^{(22)}$. The sample showed trypomastigote forms of Trypanosomatidae, which were inoculated $(0.3 \mathrm{~mL})$ in the peritoneum of 23 to 35-day-old Balb/c mice and in Liver Infusion Tryptose (LIT) axenic culture medium for the molecular identification and characterization of the parasite. After isolation, the parasite was identified as $T$. cruzi, whose strain was preserved by repeated subculturing in LIT culture medium.

\section{Growth kinetics}

The growth dynamics of the epimastigote forms of the Pm strain of T. cruzi were studied by inoculating $5 \times 10^{6}$ parasites $/ \mathrm{mL}$ in $5 \mathrm{~mL}$ of LIT medium ${ }^{(23)}$. Triple counting was performed over 10 days on a Neubauer chamber under an optical microscope.

\section{Cell invasion}

The assay for parasite invasion in the J774 cells was performed in triplicate ${ }^{(24)}$. Cells were cultivated in Roswell Park Memorial Institute (RPMI) medium 1640 supplemented with $20 \%$ fetal bovine serum (FBS), streptomycin $(100 \mu \mathrm{g} / \mathrm{mL})$, and penicillin $(100 \mathrm{U} / \mathrm{mL})$ in a humid incubator $\left(5 \% \mathrm{CO}_{2}\right)$. For the invasion assay, $1 \times 10^{6}$ parasites were seeded onto a 24 -well plate. After 72 hours, the plate was stained with Giemsa. The invasion of the $\mathrm{J} 774$ cell line by the Pm strain of $T$. cruzi was observed based on the presence of amastigote forms of the parasite within macrophages.

\section{Molecular characterization of the Pm strain of Trypanosoma cruzi and evolutionary placement}

After deoxyribonucleic acid (DNA) extraction, polymerase chain reaction was performed using 100ng genomic DNA; $100 \mathrm{ng}$ of each primer; $200 \mathrm{mM}$ of each deoxynucleotide triphosphate (dNTP); $5 \mu \mathrm{L}$ buffer solution $(200 \mathrm{mM}$ Tris- $\mathrm{HCl}$, $\mathrm{pH} 8.4,500 \mathrm{mM} \mathrm{KCl}$, and $1.5 \mathrm{mM} \mathrm{MgCl} 2) ; 2.5 \mathrm{U}$ Taq DNA polymerase and deionized with bidistilled water (qsp 50 $\mu \mathrm{L}$ ). The amplification cycle and the temperatures were defined in accordance with the primers used. DNA fragments amplified using polymerase chain reaction (PCR) were subjected to agarose gel electrophoresis $(1.5 \%)$ and then to sequencing reactions using the Big Dye Terminator kit (Perkin Elmer) in an automated sequencer ${ }^{(25)}$. The nucleotide sequences obtained from GenBank (http://www.ncbi.nlm.nih.gov/) were used as reference. The San Agustin strain of Trypanosoma rangeli was included as an external group.

\section{Ethical considerations}

This study was carried out in accordance with the recommendations of the Ethical Committee for Animal Experimentation. The protocol was approved by the Ethics Committee on Animal Use [Comissão de Ética no Uso de Animais (CEUA)] of the 
Universidade Estadual Júlio de Mesquita Filho (UNESP) at Araraquara, SP (Permit Number: 13/2012). Three Balb/c mice were studied in a controlled light and temperature environment. After the study, the mice were euthanized by $\mathrm{CO}_{2}$ and the appropriate disposal of the animals was assured by the Faculdade de Ciências Farmacêuticas de Araraquara.

\section{RESULTS}

\section{Isolation of the Pm strain of Trypanosoma cruzi}

The Pm strain of T. cruzi was identified by isolation in axenic culture medium, as well as based on its morphology (Figures 1A and B), cell infection (Figure 1C), growth kinetics (Figure 2), and molecular characterization (Figure 3). Andrade ${ }^{(26)}$ classified T. cruzi strains according to biological parameters such as the morphology of trypomastigotes and the mortality rate of the infected animals. The Pm strain of T. cruzi was inoculated in the peritoneum of $\mathrm{Balb} / \mathrm{c}$ mice. No parasites were detected in the peripheral blood of the animals, which can be a characteristic inherent to the TcI group of T. cruzi. To evaluate the invasive ability of the Pm strain, cell invasion assays were performed in triplicate in $\mathrm{J} 774$ cells, which revealed amastigote forms of the parasite within macrophages.

\section{Growth kinetics}

A growth kinetics study of the Pm strain of $T$. cruzi was conducted in triplicate, and the data are shown in Figure 2. The results of this study indicate a growth profile similar that of to the Bolivia strain of T. cruzi, which belongs to the TcI group, and different from that of the Y strain of $T$. cruzi, which has a higher ability to multiply and belongs to the TcII group.

\section{Molecular characterization and evolutionary placement}

To complete the biological characterization and to identify the group that the Pm strain of T. cruzi isolated from the
P. megistus specimen in this study belongs to, the small subunit ribosomal ribonucleic acid (SSU rRNA) gene was amplified, and its initial placement was studied. The amplification of the V7V8 region of the SSU rRNA gene resulted in products of around 900 $\mathrm{bp}^{(25)}$ (Figure 3). By using a dendrogram built after alignment of the SSU rRNA gene sequences, it was found that the Pm strain belongs to the discrete typing unit (DTU) TcI of T. cruzi.

\section{DISCUSSION}

Chagas disease has become a zoonosis since triatomines were brought from their wild ecotopes to human environments ${ }^{(12)}$. The presence of residual foci of $T$. infestans in some Brazilian states and the large number of native species of potential vectors of Chagas disease (Panstrongylus megistus, Triatoma brasiliensis, Triatoma pseudomaculata and T. sordida) found in homes are risk factors for the transmission of the disease ${ }^{(4)(27)}$.

This work reports the finding of a live male specimen of P. megistus containing potential reservoirs of $T$. cruzi in November 2011 in the Jabaquara subway yard located in the urban area of the City of São Paulo (Figure 4) next to the State Park (Table 1). In 2003 and 2007, Laboratory-Fauna (Municipality of São Paulo, Municipal Health SecretariatResponsible - Rosane Correa de Oliveira) received three specimens of $P$. megistus from areas next to the State Park, none of which tested positive for T. cruzi. In 2004, 2005, and 2007 , another three negative specimens were found about $20 \mathrm{~km}$ from the State Park (Table 1), suggesting different centers of dispersion for the species. The molecular characterization (Figure 3) performed in this study showed that the Pm strain of T. cruzi belongs to group I-TcI. Therefore, we then focused on the TcI group of T. cruzi and its transmission cycle in the urban environment. Previously, Alvarado-Otegui et al. ${ }^{(28)}$ identified the TcI and TcIII groups of $T$. cruzi in $22.7 \%$ of the studied mammals using xenodiagnosis and polymerase chain reaction in

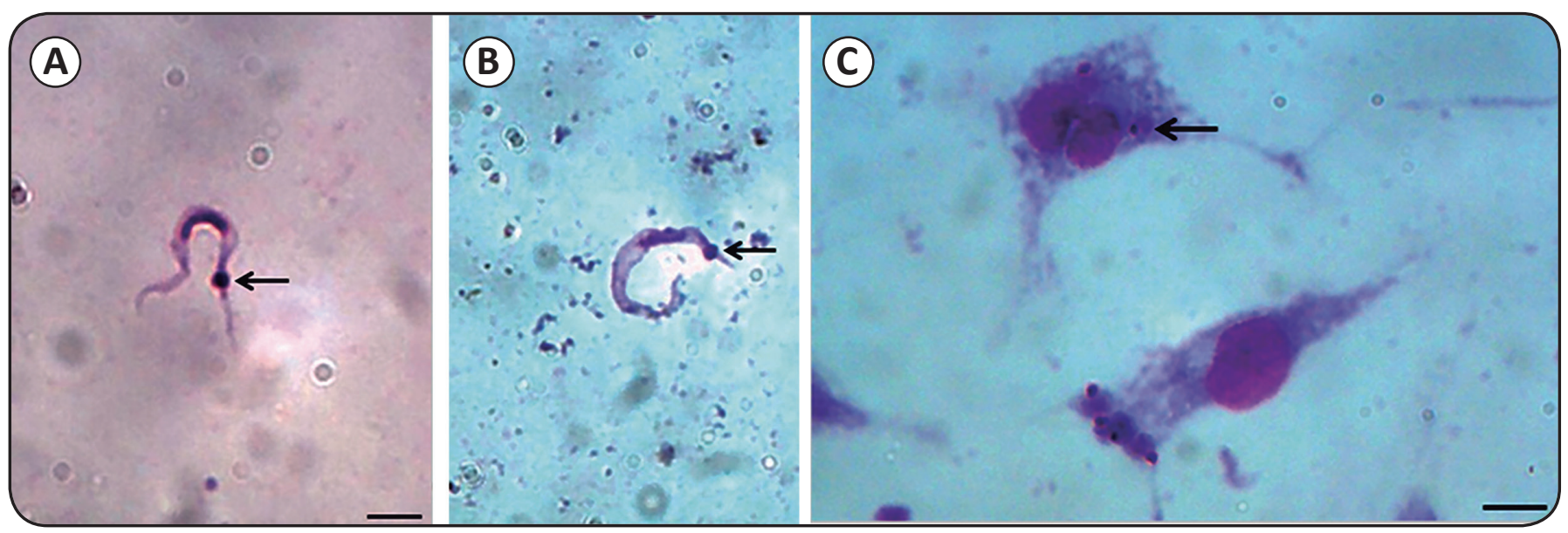

FIGURE 1 - Identification of a Trypanosoma cruzi strain isolated from Panstrongylus megistus. A, B: Trypomastigote forms of the Pm strain of Trypanosoma cruzi observed in axenic culture medium and in the intestinal content of the Panstrongylus megistus specimen. C: Arrows show the kinetoplast of the parasite. Amastigote forms of Trypanosoma cruzi in the $\mathbf{J 7 7 4}$ cell line after 72 hours of infection. Bars represent 10 $\mu \mathrm{m}$. 
a rural area in Argentina, confirming the presence of TcI in natural wild environments. The invasive ability of $T$. cruzi was observed in the $\mathrm{J} 774$ cell line with amastigote forms of the parasite found within macrophages (Figure 1C) ${ }^{(23)}$. Complementing the results of the biological analysis, the molecular characterization of the Pm strain showed that it belongs to DTU-TcI (Figure 3), which led us to hypothesize on the origin of the sample, given that the TcI group is characteristic of wild environments. Understanding the T. cruzi-DTU groups can lead to the elucidation of the epidemiological implications and to the complete understanding of the biology of the parasite ${ }^{(29)}$.

The decrease in the frequency of collection of specimens in the state of São Paulo is probably due to the captures carried out during 1984-1988 and 1992-1993 and the control actions taken along the way ${ }^{(30)}$. Martins et al. ${ }^{(27)}$ performed searches in two experimental captive sites installed in Marília, São Paulo, for a year and four months, but without successful colonization of wild triatomines. However, the capture of species infected by $T$. cruzi in the urban environment is a reason for concern,

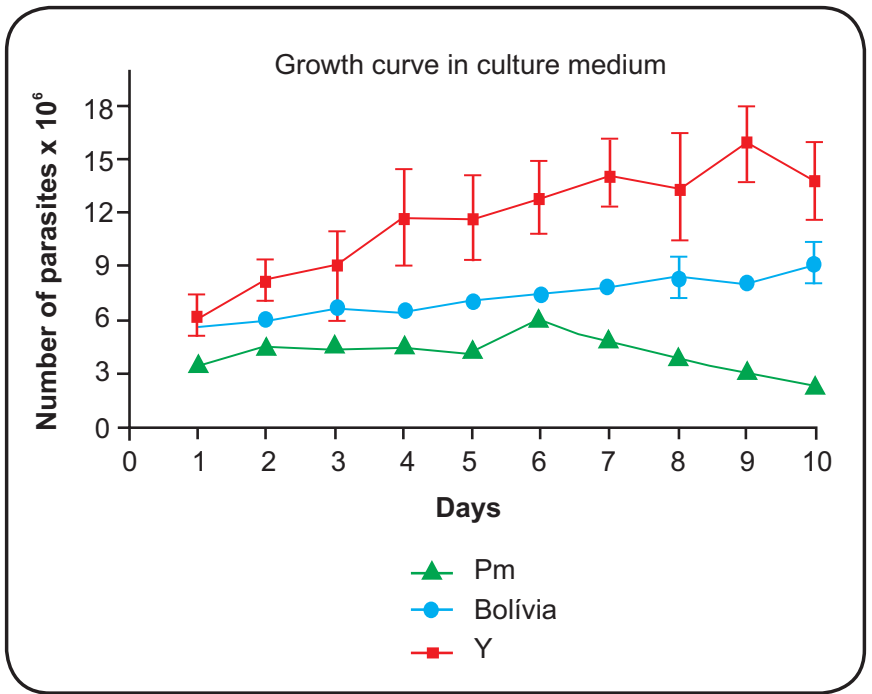

FIGURE 2 - Growth kinetics of the Pm strain of Trypanosoma cruzi in Liver Infusion Tryptose culture medium. Pm: strain of $T$. cruzi TcI; Bolívia: strain of $T$. cruzi TcI; Y: strain of $T$. cruzi TcII.

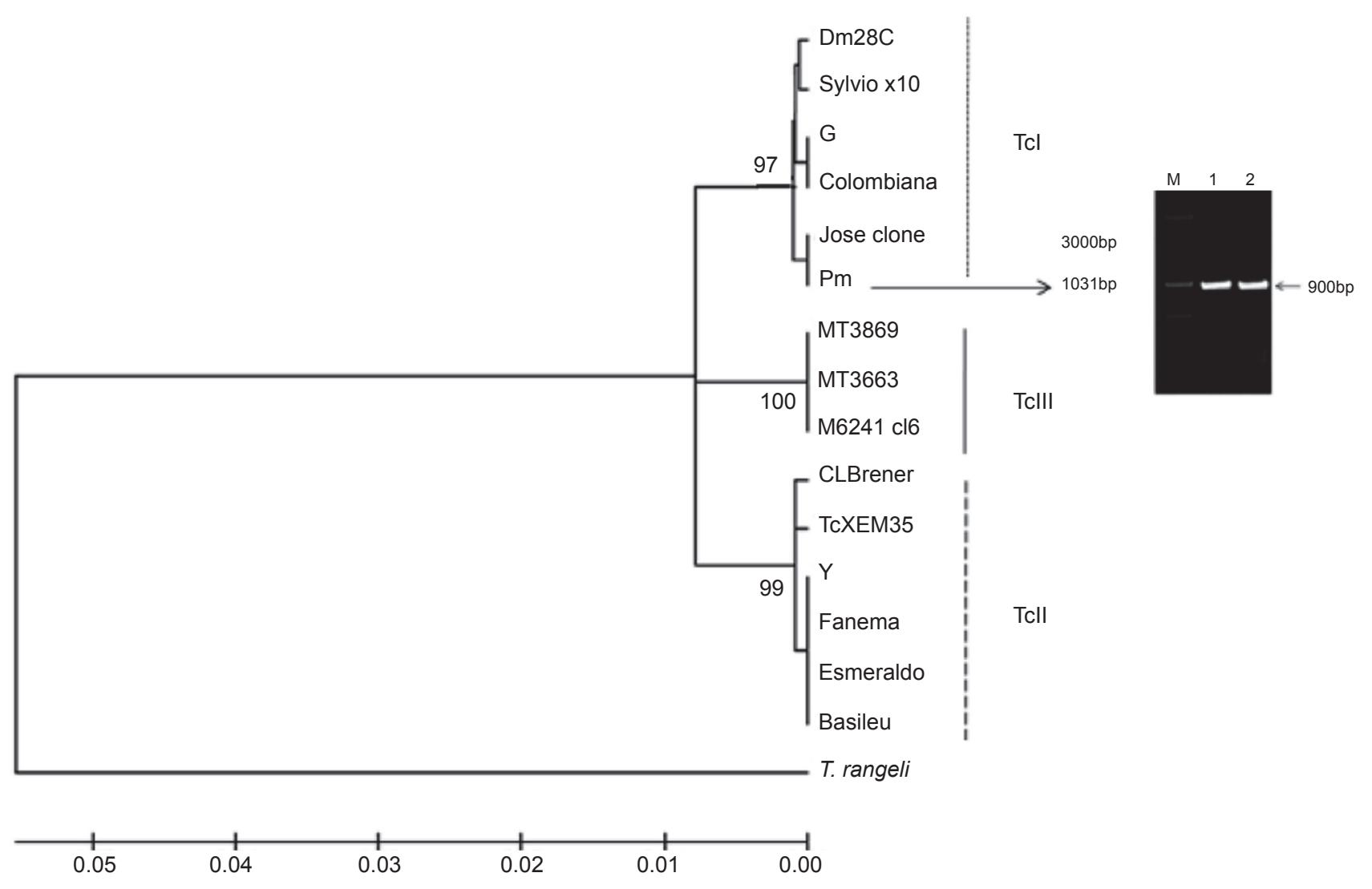

Sequences from 14 T. cruzi isolates included in the phylogenetic analysis from GenBank with acession number in bold: Dm28c AF245382.1; Sylviox10 AF303659.1; G AF239981.1; Colombiana AF239980.1; Jose clone AY785573.1; CL Brener AF245383.1; TcXEM35 AY785567.1; Y AF301912.1; Famema AY785584.1; Esmeraldo AY785564.1; Basileu AY785562.1; MT3869 AF303660.1; MT3663 AF288660.1; M6241c16 AY785578.1; and Trypanosoma rangeli AJ012417.1.

SSU rRNA: small subunit ribosomal ribonucleic acid; TcI/TcII/TcIII: discrete typing units DTUs; electrophoresis in 1.5\% agarose gel stained with GelRed®; M: molecular weight marker; Lane 1 and 2: Pm strain of T. cruzi; bp: base pair; The bars represent the expected changes per site. 


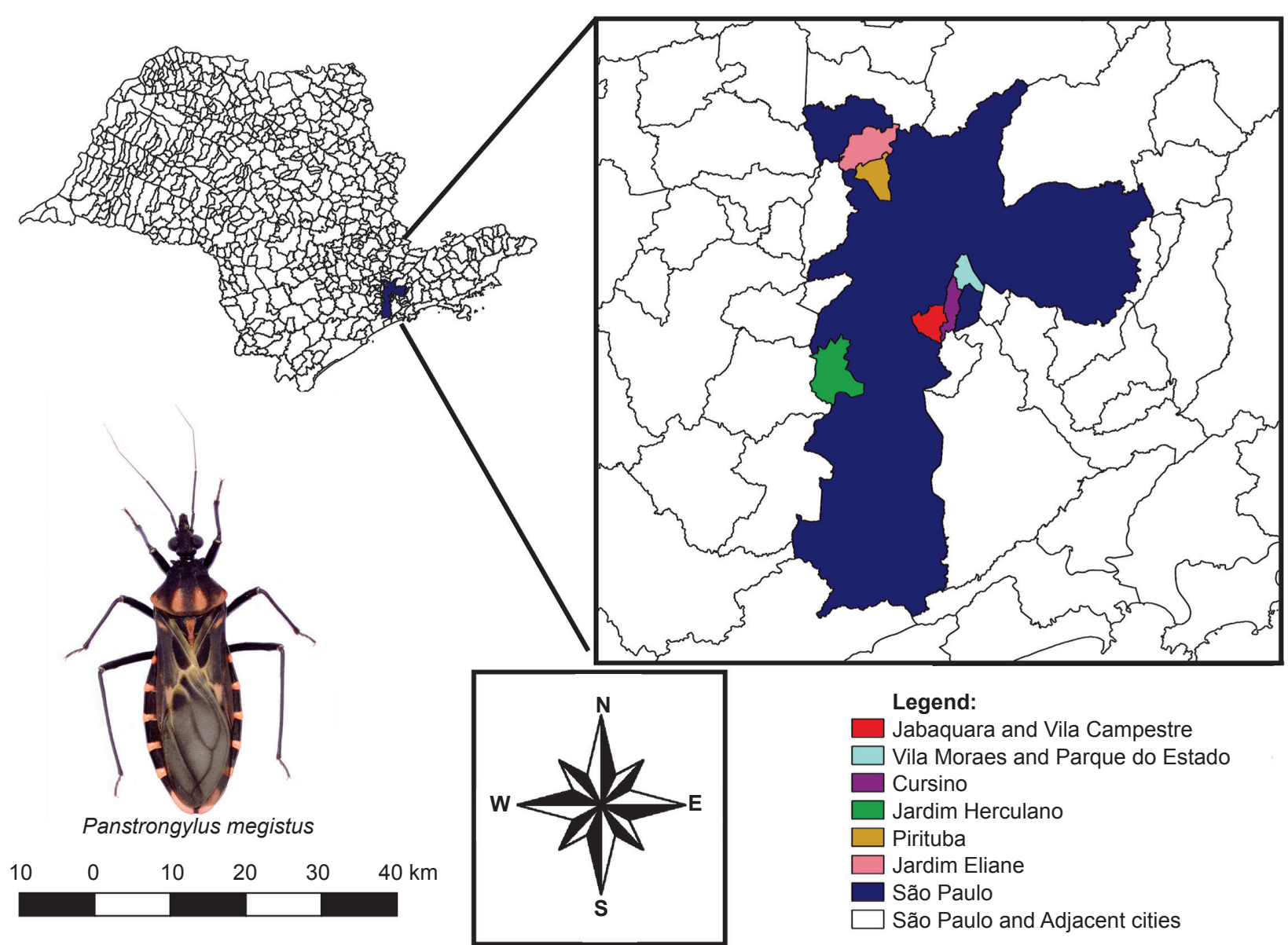

FIGURE 4 - Map showing the municipalities surveyed in the State of São Paulo, Brazil. Triatomine photo by André Teco.

TABLE 1 - Records of Panstrongylus megistus received by Laboratory-Fauna since 2003.

\begin{tabular}{llcr}
\hline Neighborhood & Address & Date & Distance from the State Park \\
\hline Vila Moraes & 1013, Eduardo Ferreira França Street & January 8, 2003 & $1.6 \mathrm{~km}$ \\
Vila Eliane & 5, Carlos Jose Spezio Street & March 12, 2004 & $25 \mathrm{~km}$ \\
Jardim Herculano & 57, Principal Street & February 15, 2005 & $23 \mathrm{~km}$ \\
Cursino & 1103, Jean da La Herta Street & January 4, 2007 & $2.2 \mathrm{~km}$ \\
Jabaquara & 215, Luís Rocha Miranda Avenue & March 6, 2007 & $2.7 \mathrm{~km}$ \\
Pirituba & 3750, Turística do Jaraguá Road & November 28, 2007 & $24 \mathrm{~km}$ \\
Vila Campestre & 134, Francisco de Paula Quintanilha Ribeiro Avenue & November 29, 2011 & $2 \mathrm{~km}$ \\
\hline
\end{tabular}

and it is recommended that cities perform continuous entomological surveillance to detect behavioral changes in the $\operatorname{species}^{(4)}(5)$.

Carvalho et al. ${ }^{(31)}$ reported the presence of 72 specimens of Rhodnius neglectus in the central area of the City of Monte Alto in São Paulo, which is $374 \mathrm{~km}$ away from São Paulo City. Their work revealed colonies of $R$. neglectus in palm trees located in the core of the city. The $R$. neglectus specimens found were not carriers of $T$. cruzi, but finding such triatomines in an urban area is an alert for the invasion of species into human environments and the possible transmission of Chagas disease as soon as the epidemiological cycle is completed. This report of $R$. neglectus in palm trees in the central area of Monte Alto was preceded by the study of Rodrigues et al. ${ }^{(32)}$ in Araçatuba, SP wich demonstrates the importance of the palm trees as a natural ecotope of triatomines, specially the Rhodinus genre. This finding can be an ecological indicator of the area with risk for Chagas disease. 
As mentioned before, P. megistus continues to be an important vector of T. cruzi in Brazil. The fact that six specimens were found within a period of four years and another one carrying $T$. cruzi was found in the Jabaquara subway yard in November 2011 indicates the need for continuous education on sanitary measures and surveillance services.

The finding of $P$. megistus in an urban area reported in our study raises two possibilities. First, the triatomine has moved from the State Park, which is around $2 \mathrm{~km}$ from the Jabaquara subway yard. The natural infection by $T$. cruzi can be related to the adaptation between mammals and triatomines living together in forest fragments such as the State Park ${ }^{(33)}$. Second, P. megistus species have been carried by birds that frequent the subway yard. The specimen found may have invaded the office through an open window or may have been transported along with some material coming from different parts of the country. The area does not provide any apparently conducive conditions for triatomine colonization, but the finding of seven specimens indicates the need for continuous surveillance.

Moreover, in this study, of $T$. cruzi was isolated from the P. megistus specimen and was characterized as belonging to the DTU-TcI group (Figure 3). Biological and molecular characterization helps understand parasite-host interactions ${ }^{(34)}$ and their evolutionary history, as demonstrated by a work published by Zingales et al. ${ }^{(29)}$, which discusses associations between vectors, ecotopes, hosts, and the six DTU. The authors point out the importance of the relation between $T$. cruzi groups and the ecoepidemiology of Chagas disease, as well as that of understanding the molecular and biological relationship between different strains of the parasite. In this regard, the current study can be helpful for research on the Pm strain of T. cruzi isolated from P. megistus based on morphology, cell invasion, growth kinetics in culture medium, and molecular characterization.

In conclusion, in this study, we isolated T. cruzi from a P. megistus found in São Paulo. After isolation, the protozoan was characterized as belonging to the TcI group. Our finding raises the possibility that this $P$. megistus specimen came from the Fontes do Ipiranga State Park, which is $2 \mathrm{~km}$ away from the place where the triatomine was found. Our results reemphasize the need for constant surveillance on $T$. cruzi infection in P. megistus as highlight the importance to search other triatomines specimens that adapted to the human environment and represent epidemiological importance during the transmission of T. cruzi. Furthermore, Chagas disease can be controlled through the interruption of the mechanism of transmission, improvement of habitation, education, basic sanitation and treatment. However, in order to have a successful control it is essential to prevent the contact between the vector and the human. Therefore, the maintenance of the epidemiological cycle of the disease would be avoided.

\section{CONFLICT OF INTEREST}

The authors declare that there is no conflict of interest.

\section{FINANCIAL SUPPORT}

Financial support was provided by Coordenação de Aperfeiçoamento de Pessoal de Nivel Superior (CAPES), Brasília, DF, Brazil; Programa de Apoio ao Desenvolvimento Cientifico (PADC), Faculdade de Ciências Farmacêuticas (FCFAR), Campus de Araraquara, Universidade Estadual Paulista (UNESP), and Instituto de Biologia (IB), Universidade Estadual de Campinas (UNICAMP). The experiments undertaken in this study comply with the current laws of the country in which they were performed (Capes).

\section{REFERENCES}

1. Galvão C (org). Vetores da doença de chagas no Brasil [online]. Curitiba: Sociedade Brasileira de Zoologia 2014; 289. Zoologia: guias e manuais de identificação series. ISBN 978-85-98203-09-6. Available from SciELO Books $<$ http://books.scielo.org $>$

2. Rosa JA, Rocha CSR, Gardim S, Pinto MC, Mendonça VJ, Ferreira Filho JCR. et al. Description of Rhodnius montenegrensis n. sp. (Hemiptera: Reduviidae: Triatominae) from the state of Rondônia, Brazil. Zootaxa 2012; 3478: 62-76.

3. Chagas C. Nova tripanozomase humana. Estudos sobre a morfologia e o ciclo evolutivo do Schizotrypanum cruzi n. gen. $\mathrm{n}$. gen. n. sp, agente etiológico de nova entidade mórbida do homem. Mem Inst Oswaldo Cruz 1909: 1:159-218.

4. Gurgel-Gonçalves R, Galvão C, Costa J, Peterson AT. Geographic Distribution of Chagas Disease Vectors in Brazil Based on Ecological Niche Modeling. J Trop Med 2012; 2012:1-15. Published online. doi:10.1155/2012/705326.

5. Galvão G, Carcavallo R, Rocha DS, Juberg J. A checklist of the current valid species of the subfamily Triatominae Jeannel, 1919 (Hemiptera, Reduviidae) and their geographical distribution, with nomenclatural and taxonomic notes. Zootaxa 2003; 202:1-36.

6. Silva RA, Bonifácio PR, Wanderley DMV. Doença de Chagas no Estado de São Paulo: comparação entre pesquisa ativa de triatomíneos em domicílios e notificação de sua presença pela população em área sob vigilância entomológica. Rev Soc Bras Med Trop 1999; 32:653-659.

7. Rocha e Silva EO, Rodrigues VLCC, Silva RA, Wanderley DMV. Programa de Controle da Doença de Chagas no Estado de São Paulo, Brasil: o controle e a vigilância da transmissão vetorial. Rev Soc Bras Med Trop 2011; 44:74-84.

8. Leite OF, Alves MJCP, Souza SSL, Mayo RC, Andrade VR, Souza CE. et al. Triatoma infestans em área sob vigilância entomológica para doença de Chagas, Estado de São Paulo, Brasil. Rev Soc Bras Med Trop 2001; 34:437-443.

9. Silva EOR, Rodrigues VLCC, Silva RA, Wanderley DMV. Programa de controle da Doença de Chagas no Estado de São Paulo, Brasil: o controle e a vigilância da transmissão vetorial. Rev Soc Bras Med Trop 2011; 44: 74-84.

10. Silva RAS, Mercado VTC, Barbosa GL, Rodrigues VLCC, Wanderley DMV. Current situation of entomological surveillance of Chagas disease in the state of São Paulo. BEPA 2011b; 8:4-13.

11. Forattini OP. Biogeografia, origem e distribuicão da domiciliação de triatomíneos no Brasil. Rev Saude Publica 1980; 14:265-299.

12. De Paula MBC, Da Costa IN, Freitas PA, Limongi JE, Pajuaba Neto AA, Pinto RMC, et al. Occurrence of positivity for Trypanosoma cruzi in triatomine from municipalities in Southeastern Brazil, from 2002 to 2004. Rev Soc Bras Med Trop 2010; 43: 9-14. 
13. Barreto MP. Ecologia de Triatomíneos e transmissão do Trypanosoma cruzi, com especial referência ao Brasil. Rev Soc Bras Med Trop 1976; 10:339-353.

14. Costa J, Lorenzo M. Biology, diversity and strategies for the monitoring and control of triatomines - Chagas disease vectors. Mem Inst Oswaldo Cruz 2009; 104:46-51.

15. Cordovez JM, Rendon LM, Gonzalez C, Guhl F. Using the basic reproduction number to assess the effects of climate change in the risk of Chagas disease transmission in Colombia. Acta Trop 2014; 129:74-82.

16. Gomes JF. Triatomas e molestia de Chagas no Estado de São Paulo. 1916. I Congresso Med Paulista. 1917; 2:193-214.

17. Carcavallo RU, Franca Rodríguez ME, Salvatella R, Curto de Casas SI, Sherlock IS, Galvão C, et al. Hábitats e fauna relacionada. In: Carcavallo RU, Galíndez Girón I, Jurberg J, Lent H, orgs. Atlas dos Vetores da Doença de Chagas nas Américas. Vol. II. Rio de Janeiro: FIOCRUZ. 1998; p. 561-619.

18. Barretto MP, Siqueira AF, Pedreira de Freitas JL. Estudo sobre reservatórios e vetores do Trypanosoma cruzi II - Encontro do Panstrongylus megistus em ecótopos silvestres no Estado de São Paulo (Hemiptera, Reduviidae). Rev Inst de Med Trop de São Paulo 1964; 6:56-63.

19. Forattini OP, Rabello EX, Castanho MLS, Pattoli DGB. Aspectos ecológicos da tripanossomose americana I - Observações sobre Panstrongylus megistus e suas relações com focos naturais da infecção em área urbana da cidade de São Paulo, Brasil. Rev Saude Publica 1970; 4:19-30.

20. Barreto MP. Estudos sobre reservatórios e vectores silvestres do Trypanosoma cruzi. XXXI: Observações sobre a associação entre reservatórios e vectores, com especial referência è Região Nordeste do Estado de São Paulo. Rev Bras Biol 1968; 28:481-494.

21. Barretto MP. Nuevos conceptos ecológicos en Ia epidemiologia de Ia Enfermedad de Chagas. Mem II Congr Centroamer y I Nac Microbiol, Panama: 1971. p. 131-147.

22. Ribeiro RA, Mendonça VJ, Alves RT, Martinez I, Araújo RF, Melo F. et al. Trypanosoma cruzi strains from triatomine collected in Bahia and Rio Grande do Sul, Brazil. Rev Saude Publica 2014; 48:295-302.

23. Yoshida N. Molecular basis of mammalian cell invasion by Trypanosoma cruzi. An Acad Bras Cienc 2006; 78:87-111.

24. Muelas-Serrano S, Le-Senne A, Fernandéz-Portillo C, Nogal JJ, Ochoa C, Goméz-Barrio A. In vitro and in vivo anti-Trypanosoma cruzi activity of a novel nitro-derivated. Mem Inst Oswaldo Cruz 2002; 97: 553-557.
25. Lima L, Silva FM, Neves L, Attias M, Takata CSA, Campaner M, et al. Evolutionary insights from bat trypanosomes: morphological, developmental and phylogenetic evidence of a new species, Trypanosoma (Schizotrypanum) erneyi sp. nov., in African bats closely related to Trypanosoma (Schizotrypanum) cruzi and allied species. Protist 2012; 163:856-872.

26. Andrade SG. Caracterização de cepas do Trypanosoma cruzi isoladas no Recôncavo Baiano (Contribuição ao estudo da patologia geral da Doença de Chagas em nosso meio). Rev Pat Trop 1974; 3:65-121.

27. Martins LPA, Castanho REP, Tonon FF, Unterleider CE, Rosa JA. Using captive sentinels to collect wild Triatomines in the Region of Marília-SP, Brazil. Rev Patol Trop 2013: 42:96-104.

28. Alvarado-Otegui JA, Ceballos LA, Orozco MM, Enriquez GF, Cardinal MV, Cura $\mathrm{C}$, et al. The sylvatic transmission cycle of Trypanosoma cruzi in a rural area in the humid Chaco of Argentina. Acta Trop 2012; 124:79-86.

29. Zingales B, Miles MA, Campbell DA, Tibayrenc M, Macedo AM, Teixeira MMG, et al. The revised Trypanosoma cruzi subspecific nomenclature: rationale, epidemiological relevance and research applications. Infect Genet Evol 2012; 12:240-253.

30. Organización Panamericana de la Salud. Guía para muestreo en actividades de vigilancia y control vectorial de la enfermedad de Chagas. 2003; No. 276: Spain.

31. Carvalho DB, Almeida CE, Rocha CS, Gardim S, Mendonça VJ, Ribeiro AR, et al. A novel association between Rhodnius neglectus and the Livistona australis palm tree in an urban center foreshadowing the risk of Chagas disease transmission by vectorial invasions in Monte Alto City, São Paulo, Brazil. Acta Trop 2014; 130:35-38.

32. Rodrigues VLCC, Silva RAS, Wanderley DMV, Carvalho ME, Junior CP. Detecção de triatomíneos da espécie Rhodnius neglectus em área urbana de municípios da região de Araçatuba. BEPA 2009; 6:20-23.

33. Orozco MM, Enriquez GF, Alvarado-Otegui JA, Cardinal MV, Schijman AG, Kitron U. New Sylvatic Hosts of Trypanosoma cruzi and Their Reservoir Competence in the Humid Chaco of Argentina: A Longitudinal Study. Am J Trop Med Hyg 2013; $88: 872-882$.

34. Rimoldi A, Tomé AR, Ambrósio DL, Fernandes MZT, Martinez I, Araújo RF, et al. Morphological, biological and molecular characterization of three strains of Trypanosoma cruzi Chagas, 1909 (Kinetoplastida, Trypanosomatidae) isolated from Triatoma sordida (Stal) 1859 (Hemiptera, Reduviidae) and a domestic cat. Parasitology 2012; 139: 37-44. 